\title{
The Prevalence of Overweight and Obesity among Students between the Ages of 6 and 15 years in Konya
}

\author{
Șükran Arıkan' (D, Yetkin Utku Kamuk² (1), Serkan Revan ${ }^{3}$ (1) \\ 'Department of Trainer Education, Faculty of Sport Sciences, Selçuk University, Konya, Turkey \\ ${ }^{2}$ Department of Trainer Education, Faculty of Sport Sciences, Hitit University, Çorum, Turkey \\ ${ }^{3}$ Department of Recreation, Faculty of Sport Sciences, Selçuk University, Konya, Turkey
}

ORCID iDs of the authors: Ș.A. 0000-0002-2625-0898; Y.U.K. 0000-000I-5976-7503; S.R. 0000-0002-9056-35I4.

Cite this article as: Arıkan Ș, Kamuk YU, Revan S. The Prevalence of Overweight and Obesity among Students between the Ages of 6 and 15 years in Konya. Cyprus J Med Sci 2020; 5(3): 234-8.

\section{BACKGROUND/AIMS}

This study was conducted to determine the prevalence of overweight and obesity among primary school students.

\section{MATERIAL and METHODS}

A total of 10781 students (5622 boys, 5159 girls) aged 6-15 years participated in the study. Descriptive statistics of the data were expressed as mean, standard deviation, maximum, minimum, and range values. The Kolmogorov-Smirnov test was applied and Q-Q plot analysis was performed visually to determine if the data was normally distributed. Since the data were not normally distributed, the LMS (Lambda for the skew, Mu for the median, and Sigma for the generalized coefficient of variation) method was used to calculate the percentiles.

\section{RESULTS}

The prevalence of overweight was $7.4 \%$ in both sexes, while the prevalence of obesity was $5.8 \%$ for boys and $5.3 \%$ for girls. The age group with the highest prevalence of overweight was 13 years $(9.6 \%)$ in boys and 15 years (13.5\%) in girls, while that with the highest prevalence of obesity was found to be 8 and 10 years $(6.6 \%)$ in boys and 8 years $(6.5 \%)$ in girls.

\section{CONCLUSION}

It is remarkable that obesity is high in both sexes, especially in young children. Preventive interventions to stop this trend are recommended to focus on the early stages of childhood.

Keywords: Childhood obesity, students, overweight, prevalence

\section{INTRODUCTION}

Obesity is characterized by an increase in adipose tissue that leads to many chronic diseases and premature deaths and is a worldwide global epidemic (I). Obesity, which is an important cause of morbidity due to hypertension, dyslipidemia, insulin resistance, and severe psychological stress, is increasingly being observed in childhood (2). Childhood obesity is one of the most serious public health problems of the 2 lst century. The problem is global and affects many low and middle-income countries regularly, especially in urban settings. Overweight and obese children are more likely to become obese in adulthood and may develop noncommunicable diseases such as diabetes and cardiovascular diseases at a younger age (3). It also contributes to an increase in health expenditures. For all these reasons, it is important to prevent childhood and to identify overweight and obese children at an early stage, so that they can start treatment to gain and maintain a healthy weight (4).

One of the most reliable indicators for assessing a child's health is the weight and height measurements by age. Anthropometric measurements are the most commonly used methods for evaluating the nutritional status of not only individuals, but also the society. Although the standards proposed by the World Health Organization are suggested to be valid for almost every country in the first years of life, differences can be detected between societies at this early age (5).

This study was conducted to determine the prevalence of overweight and obesity among primary school students. 


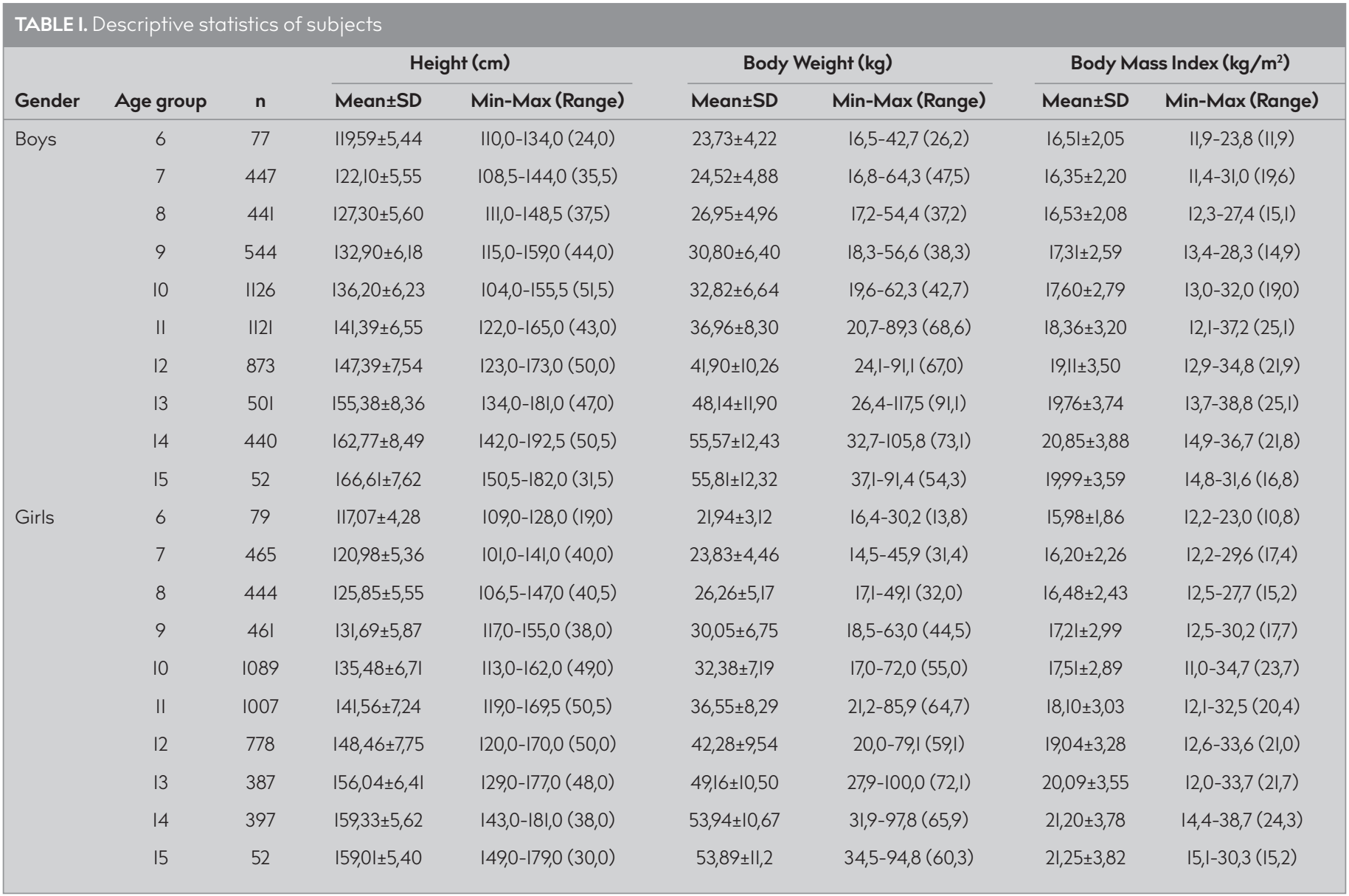

\section{MATERIAL and METHODS}

The study was conducted on a total of 10781 ( 5622 boys, 5159 girls) students in the 6-15 years age group studying in 16 primary schools in Konya city center. The necessary permission for the study was obtained from the Provincial Directorate of National Education and the schools were informed before the study. Body weight measurements of children were obtained with light weight clothes and without shoes and jackets by electronic weighing with a sensitivity of $\pm 100 \mathrm{gr}$. Height measurements were taken with the shoes removed, heels combined, hip, and shoulders based on the wall with I-mm spacing.

The study was conducted in accordance with the Declaration of Helsinki, and the protocol was approved by the Ethics Committee of Selçuk University Faculty of Sports Science Non-interventional Clinical Research. Prior to the study, the subjects were

\section{Main Points:}

- Obesity is characterized by an increase in adipose tissue and is a worldwide global epidemic.

- In this study, the prevalence of overweight and obesity among primary school students were determined.

- The prevalence of overweight was $7.4 \%$ in both sexes, while the prevalence of obesity was $5.8 \%$ for boys and $5.3 \%$ for girls.

- As a result, it is striking that obesity is high in both genders, especially in young children. informed about the study, and their written consent stating that they agreed to participate in the study were received.

\section{Statistical Analysis}

Considering the obtained data, mean and standard deviation valves were used to calculate the percentile values $(5,10,25,50,75,90$, and 95) for each sex and age group. For each category, based on statistical Z-scores, the expected BMI was calculated according to how many Z-points are away from the average. However, because the 85th percentile for BMl was the recommended threshold value for "overweight" classification for children and adolescents $(6,7), 85 \%$ was also included in the calculations and for the "overweight" category as the cut-off point. Descriptive statistics of the data are given as mean, standard deviation, maximum, minimum, and interval. The Kolmogorov-Smirnov test and Q-Q plot analysis were used to test the normal distribution of the data. The following formula (8) is used to calculate the values:

$$
Z_{L M S}=\frac{1}{\sigma_{L} \lambda}\left[\left(\frac{y}{\mu}\right)^{\lambda}-1\right]
$$

Reference values were calculated for each age group using the calculated $Z$ values for the obtained critical percentile values.

\section{RESULTS}

In Table I, average, minimum, maximum, and standard deviation values of height, body weight, and body mass index variables are given according to the age groups for girls and boys. 
It was found that BMl values did not meet the normal distribution assumption according to the Kolmogorov-Smirnov test results $(p<0.01)$ (Table 2$)$.

Table 3 shows the percentile values of the body mass index according to the age groups of the boys.

The distribution by the BMl categories for boys is shown in Table 4. Accordingly, the "overweight" prevalence of boys aged 6-15 years ranged from $2.6 \%$ to $9.6 \%$ (overall prevalence $7.4 \%$ ), and the highest prevalence was found to be in the 13 -year category $(9.6 \%)$. When the obesity prevalence was examined, it was found that the children in the 8 and 10 years age groups had the

\begin{tabular}{|c|c|c|c|}
\hline & \multicolumn{3}{|c|}{ Kolmogorov-Smirnov } \\
\hline & Statistical Value & df & $p$ \\
\hline Boy & 0.124 & 5622 & $0.00^{*}$ \\
\hline Girl & 0.101 & 5159 & $0.00^{*}$ \\
\hline
\end{tabular}

highest obesity prevalence (6.6\%) and the overall obesity prevalence was $5.8 \%$ (Table 4 ).

Table 5 shows the percentile values of body mass index according to the age groups of girls.

The distribution by BMl categories for girls is shown in Table 6. Accordingly, the "overweight" prevalence of girls between the ages of 6 - 15 years ranged from $4.9 \%$ to $13.5 \%$ (overall prevalence $7.4 \%$ ), and the highest prevalence was found to be in the 15 -year category (13.5\%). When the prevalence of obesity was examined, it was found that children in the 8-year age group had the highest obesity prevalence (6.5\%) and the overall obesity prevalence was $5.3 \%$ (Table 6 ).

\section{DISCUSSION}

To determine the prevalence of overweight and obesity among primary school students, the prevalence of overweight was $7.4 \%$ in both sexes; the prevalence of obesity was $5.8 \%$ for boys and $5.3 \%$ for girls. The age group with the highest prevalence of overweight was 13 years $(9.6 \%)$ in males and 15 years $(13.5 \%)$ in females; The highest prevalence of obesity was found in the age range of 8 and 10 years $(6.6 \%)$ in boys and 8 years $(6.5 \%)$ in girls (Table 4,6$)$.

TABLE 3. BMI percentile values for boys

\begin{tabular}{|c|c|c|c|c|c|c|c|c|}
\hline Age & $5 \%$ & \multicolumn{7}{|c|}{ Percentiles } \\
\hline 6 & 13.44 & 14.06 & 15.19 & 16.51 & 17.94 & 18.78 & 19.37 & 20.25 \\
\hline 7 & 13.09 & 13.74 & 14.94 & 16.35 & 17.89 & 18.80 & 19.44 & 20.40 \\
\hline 8 & 13.42 & 14.05 & 15.19 & 16.53 & 17.98 & 18.84 & 19.44 & 20.33 \\
\hline 9 & $|3.5|$ & 14.26 & 15.66 & 17.31 & 19.13 & 20.22 & 20.98 & 22.14 \\
\hline$\|$ & 13.75 & 14.65 & 16.33 & 18.36 & 20.63 & 22.00 & 22.97 & 24.45 \\
\hline 12 & $|4| \mid$. & 15.08 & 16.90 & 19.11 & 21.60 & 23.11 & 24.18 & 25.82 \\
\hline 13 & 14.44 & 15.47 & 17.40 & 19.76 & 22.43 & 24.04 & 25.20 & 26.96 \\
\hline 14 & 15.32 & 16.39 & 18.40 & 20.85 & 23.61 & 25.29 & 26.48 & 28.30 \\
\hline
\end{tabular}

TABLE 4. Distribution by BMl categories for boys

\begin{tabular}{|c|c|c|c|c|c|c|c|c|}
\hline \multirow[b]{2}{*}{ Age } & \multicolumn{2}{|c|}{ Weak } & \multicolumn{2}{|c|}{ Normal } & \multicolumn{2}{|c|}{ Overweight } & \multicolumn{2}{|c|}{ Obese } \\
\hline & $\mathrm{n}$ & $\%$ & $n$ & $\%$ & $\mathrm{n}$ & $\%$ & n & $\%$ \\
\hline 6 & 1 & 1.3 & 69 & 89.6 & 2 & 2.6 & 5 & 6.5 \\
\hline 8 & 8 & 1.8 & 377 & 85.5 & 27 & 6.1 & 29 & 6.6 \\
\hline 9 & 5 & 0.9 & 464 & 85.3 & 40 & 7.4 & 35 & 6.4 \\
\hline ॥ & 13 & 1.2 & 953 & 85.0 & 96 & 8.6 & 59 & 5.3 \\
\hline 12 & 10 & I.I & 743 & 85.1 & 72 & 8.2 & 48 & 5.5 \\
\hline 13 & 7 & 1.4 & 424 & 84.6 & 48 & 9.6 & 22 & 4.4 \\
\hline 14 & 9 & 2.0 & 369 & 83.9 & 35 & 8.0 & 27 & 6.1 \\
\hline
\end{tabular}




\begin{tabular}{|c|c|c|c|c|c|c|c|c|}
\hline \multirow[b]{2}{*}{ Age } & \multirow[b]{2}{*}{$5 \%$} & \multicolumn{7}{|c|}{ Percentiles } \\
\hline & & $10 \%$ & $25 \%$ & $50 \%$ & $75 \%$ & $85 \%$ & $90 \%$ & $95 \%$ \\
\hline 7 & 12.86 & 13.53 & 14.75 & 16.20 & 17.78 & 18.72 & 19.38 & 20.38 \\
\hline 8 & 12.91 & 13.62 & 14.93 & 16.48 & 18.19 & 19.20 & 19.92 & 21.00 \\
\hline 10 & 13.32 & 14.14 & 15.67 & 17.51 & 19.55 & 20.78 & 21.65 & 22.97 \\
\hline II & 13.72 & 14.57 & 16.18 & 18.10 & 20.24 & 21.53 & 22.45 & 23.83 \\
\hline 12 & $|4.3|$ & 15.23 & 16.96 & 19.04 & 21.37 & 22.76 & 23.76 & 25.27 \\
\hline 13 & 14.99 & 15.98 & 17.84 & 20.09 & 22.61 & 24.13 & 25.21 & 26.86 \\
\hline
\end{tabular}

TABLE 6. Distribution by BMl categories for girls

\begin{tabular}{|c|c|c|c|c|c|c|c|c|}
\hline \multirow[b]{2}{*}{ Age } & \multicolumn{2}{|c|}{ Weak } & \multicolumn{2}{|c|}{ Normal } & \multicolumn{2}{|c|}{ Overweight } & \multicolumn{2}{|c|}{ Obese } \\
\hline & $\mathbf{n}$ & $\%$ & $\mathrm{n}$ & $\%$ & $\mathbf{n}$ & $\%$ & $\mathbf{n}$ & $\%$ \\
\hline 6 & I & 1.3 & 66 & 83.5 & 7 & 8.9 & 5 & 6.3 \\
\hline 8 & 1 & 0.2 & 390 & 87.8 & 24 & 5.4 & 29 & 6.5 \\
\hline 9 & 3 & 0.7 & 403 & 87.4 & 34 & 7.4 & 21 & 4.6 \\
\hline ॥ & 23 & 2.3 & 846 & 84.0 & 86 & 8.5 & 52 & 5.2 \\
\hline 12 & 17 & 2.2 & 662 & 85.1 & 56 & 7.2 & 43 & 5.5 \\
\hline 13 & 10 & 2.6 & 327 & 84.5 & 33 & 8.5 & 17 & 4.4 \\
\hline 14 & 16 & 4.0 & 332 & 83.6 & 29 & 7.3 & 20 & 5.0 \\
\hline
\end{tabular}

According to the 2015-2016 data, the prevalence of obesity in the United States was higher among youths aged 6-II years (18.4\%) and adolescents aged $12-19$ years (20.6\%) compared with children aged $2-5$ years (13.9\%) (9). In Nigeria, with an average age of 14.6 years, $2.1 \%$ of children were overweight and $1.7 \%$ were obese (10). In a study that investigated a systematic review of childhood obesity in the Middle East and North Africa, the prevalence of overweight and obesity in Kuwait was $25.6 \%$ and $34.8 \%$ among young boys, and $20.8 \%$ and $20.5 \%$ among girls (II). In studies conducted in different regions of our country, $5 \%-13.8 \%$ of the children were found to be overweight and $4.9 \%-20.7 \%$ were obese (12-16). In a study conducted in semi-rural children aged 6-14, it was determined that approximately one out of every three children were overweight or obese, while boys were overweight and obese $(17.7 \%$ and $15.2 \%$ ) and girls (13.3\% and $9.2 \%$ ) (17). Our data support the fact that overweight and obesity are an increasing public health problem.

In these studies, the frequency of obesity among the students; sex, child's birth weight, parent's body mass index, high socio-economic level, high maternal education, number of obese relatives, feeding habits, parents' dissatisfaction with the child's weight, sport activity, time spent in front of a computer and television, and nutrition preferences were reported (I3, I8-22). In a study, it was found that the prevalence of obesity increased significantly in rural areas and that the awareness of the families about their children's weight was low and it was concluded that the family-based approach to combating childhood obesity should be strengthened and the number of parental education should be increased (I5). To detect the excess weight and obesity problems early and take the necessary precautions, it is necessary to monitor the body weight, height, and body mass index of the students from an early age. In addition, national health policies and social responsibility projects should focus more on combating child and adolescent obesity and developing solution-oriented policies (23). Öztürk and Aktürk (24) found that the prevalence of overweight and obesity was significantly higher in the 5-8 years age group and in students in schools classified as socioeconomically good. Therefore, they stressed the need to raise awareness of families and students about this problem, which is likely to increase in the coming years, by using other channels, such as health personnel and the media. In this study, physical activity levels and nutrition habits of 7-14 year-old students were examined to increase the level of physical activity and activities to be combined with healthy eating habits that 
could prevent future health problems and healthy aging awareness in early ages, with the right interaction with other family members who are more active (25).

In conclusion, as a result, further research is needed to fully investigate the role of a sedentary life style, nutrition, and other specific risk factors, to manage this common and growing health problem, and to evaluate various interventions. There is an increasing tendency to obesity in our country, especially at young ages. We recommend that health policy makers prioritize early childhood to stabilize this rising trend and implement intervention strategies.

Ethics Committee Approval: Ethics committee approval was received for this study from the ethics committee of Selçuk University Faculty of Sports Science Non-interventional Clinical Research.

Informed Consent: Written informed consent was obtained from the students who participated in this study.

Peer-review: Externally peer-reviewed.

Author contributions: Concept - Ș.A., S.R.; Design - S.A., S.R.; Supervision - S..A.; Fundings - Y.U.K.; Materials - Y.U.K.; Data Collection and/or Processing - S.R.; Analysis and/or Interpretation - Y.U.K.; Literature Search - ȘA., S.R.; Writing - Ș.A., S.R.; Critical Reviews - Ș.A., S.R.

Conflict of Interest: Authors have no conflicts of interest to declare.

Financial Disclosure: The authors declared that this study has received no financial support.

\section{REFERENCES}

I. Racette SB, Deusinger SS, Deusinger RH. Obesity: overview of prevalence, etiology, and treatment. Phys Ther 2003; 83: 276-88. [Crossref]

2. Babaoğlu K, Hatun Ș. Çocukluk çağında obezite. STED 2002; II(I): 8-I0.

3. WHO (World Health Organization), 2019. https://www.who.int/dietphysicalactivity/childhood/en/.

4. Koyuncuoğlu Güngör N. Overweight and obesity in children and adolescents. J Clin Res Pediatr Endocrinol 2014; 6(3): 129-43. [Crossref]

5. Neyzi O, Günöz H, Furman A, Bundak R, Gökçay G, Darendeliler F, et al. Türk çocuklarında vücut ağırlığı, boy uzunluğu, baș çevresi ve vücut kitle indeksi referans değerleri. Çocuk Sağlığı ve Hastalıkları Dergisi 2008; 5I: I-14.

6. Himes JH, Dietz WH. Guidelines for overweight in adolescent preventive services: recommendations from an expert committee. The expert committee on clinical guidelines for overweight in adolescent preventive services. Am J Clin utr 1994; 59(2): 307-16. [Crossref]

7. Barlow SE, Dietz WH. Obesity evaluation and treatment: Expert committee recommendations. Pediatrics 1998; 102(3): e29. [Crossref]

8. Indrayan A. Demystifying LMS and BCPE methods of centile estimation for growth and other health parameters. Indian Pediatr 20I4; 5I(I): 37-43. [Crossref]
9. Hales CM, Carroll MD, Fryar CD, Ogden CL. Prevalence of obesity among adults and youth: United States, 2015-2016. NCHS Data Brief 2017; 288: I-8.

10. Adebimpe WO. Prevalence and knowledge of risk factors of childhood obesity among school-going children in Osogbo, south-western Nigeria. Malawi Med J 2019; 3I(I): 19-24. [Crossref]

II. Farrag NS, Cheskin LJ, Farag MK. A systematic review of childhood obesity in the Middle East and North Africa (MENA) region: Prevalence and risk factors meta-analysis. Adv Pediatr Res 2017; 4: 8. [Crossref]

12. Tütüncü i. Kastamonu il merkezinde 13 ilköğretim okulunda 5-15 yaș grubu öğrencilerde fazla kiloluluk ve obezite prevalansı. ACU Sağlık Bil Derg 20|4; 5(2): |4|-5|.

13. Özilbey P, Ergör G. İzmir Illi Güzelbahçe Illçesi'nde ilköğretim öğrencilerinde obezite prevalansı ve beslenme alıșkanlıklarının belirlenmesi. Turkish Journal of Public Health 2015; I3(I): 30-9. [Crossref]

14. Yıldıım Aksakal B, Oğuzöncül AF. Elazığ kent merkezinde bulunan ortaöğretimde okuyan öğrencilerde obezite sıklığı ve etkileyen faktörlerin incelenmesi. Dicle Tıp Dergisi 20I7; 44 (I): 13-24. [Crossref]

15. Agadayı E, Çelik N, Çetinkaya S, Nemmezi Karaca S. Sivas ili kırsal bir ilçede okul çağı çocuklar ve adolesanlarda obezite sıklığının ve etkileyen faktörlerin belirlenmesi. Ankara Med Journal 2019; 19(2): 325-36. [Crossref]

16. Yazar A, Kılıçaslan M, Akın F, Arslan Ș. Konya Illinde 6-18 Yaș Arası Çocuklarda Obezite Sıklığı. Bozok Tıp Dergisi 2019; 9(1): 123-9. [Crossref]

17. Ergin A, Meydan Acımıș N, Özdemir C, Akbay B, Kınacı Çimen Y, Uzuner N, et al. Yarı kırsal alanda 6-14 yaș grubu çocuklarda obezite sıklığı ve ilișkili faktörler. Pamukkale Tıp Dergisi 2019; 12(3): 475-84. [Crossref]

18. Savașhan Ç, Sarı O, Aydoğa Ü, Erdal M. İlkokul çağındaki çocuklarda obezite görülme sıklığı ve risk faktörleri. Türk Aile Hek Derg 20l5; 19 (I): |4-21. [Crossref]

19. Seremet Kürklü N, Gökmen Özel H. Farklı sosyoekonomik düzeydeki ortaokul öğrencilerinin beslenme durumu ve obezite sıklığının belirlenmesi. Bes Diy Derg 2015; 43(2): 100-10.

20. Çınar S, Çavușoğlu H. Farklı Sosyo-ekonomik düzeylerdeki 7-ı4 yaș grubu çocuklarda obezitenin incelenmesi. Turkiye Klinikleri J Nurs Sci 2016; 8(2): II2-2I. [Crossref]

21. Yilmaz M, Mayda A. Determination of the obesity prevalence and risk factors in school children in Duzce. Düzce Tıp Fakültesi Dergisi 2018; 19(2): 42-7.

22. Yılmaz M, Ağartıoğlu Kundakçı G, Dereli F, Özgüven Öztornacı B, Egelioğlu Çetișli N. Illköğretim öğrencilerinde yaș ve cinsiyete göre obezite ve ilișkili özellikler obezite ve ilișkili faktörler. Güncel Pediatri 2019; I7(I): 127-40.

23. Daștan I, Çetinkaya $\vee$, Delice ME. İzmir ilinde 7-I8 yaș arası öğrencilerde obezite ve fazla kilo prevalansı. Bakırköy Tıp Dergisi 2014; 10: 139-46. [Crossref]

24. Öztürk $A, A k t u ̈ r k ~ S$. İlköğretim öğrencilerinde obezite prevalansı ve ilișkili risk faktörleri. TAV Prev Med Bull 20ll; 10: 53-60.

25. Konca E, Ermiș E, Ermiș A, Erilli NA. 7-I4 yaș öğrencilerin fiziksel aktivite durumları ve beslenme alıșkanlıklarının araștırılması. Turkish Studies-Social Sciences 2019; 14(I): 105-17. [Crossref] 